Vol 2 No 2, Mei - July 2019. pp.75 - 83. Journal PUBLICUHO Faculty of Social and Political Sciences Halu Oleo University, Kendari, Southeast Sulawesi, Indonesia. ISSN 2621-1351 (online), ISSN 2685-0729 (print) Open Access at:

http://ojs.uho.ac.id/index.php/PUBLICUHO/index

\title{
ANALISIS HUBUNGAN SISTEM INFORMASI MANAJEMEN DENGAN EFEKTIVITAS KERJA PEGAWAI NEGERI SIPIL PADA BAGIAN PENGOLAHAN DATA ELEKTRONIK PROVINSI SULAWESI TENGGARA
}

\author{
1 Sahrun \\ ${ }^{1}$ Fakultas IImu Sosial dan IImu Politik Universitas Halu Oleo \\ sahrunmane@gmail.com
}

\begin{abstract}
This study aims to determine the implementation of management information systems and the effectiveness of Civil Servants work in the Electronic Data Processing Section of Southeast Sulawesi Province, and to find out the relationship between Management Information Systems and the Effectiveness of Civil Servants Work in the Electronic Data Processing Section of Southeast Sulawesi Province.

The population in this study were all employees with the status of Civil Servants working in the Electronic Data Processing Section of Southeast Sulawesi Province, totaling 32 people. Sampling is done by using the saturated sample method (census), which is to use the entire population as a sample (respondent) besides that it is used by 2 informants namely the Head of Section and Head of the Electronic Data Processing Subdivision.

In this study used product moment correlation analysis and qualitative analysis.

The results of the study showed that the management information system used by the Electronic Data Processing Section of Southeast Sulawesi Province had on average been good, and the work effectiveness of civil servants in the Electronic Data Processing Section of Southeast Sulawesi Province was also good on average.
\end{abstract}

Keywords: Electronic Data Processing; Management Information Systems; Work Effectivenes

\begin{abstract}
Abstrak
Penelitian ini bertujuan untuk mengetahui pelaksanaan sistem informasi manajemen dan efektifitas kerja Pegawai Negeri Sipil pada Bagian Pengolahan Data Elektronik Provinsi Sulawesi Tenggara, dan untuk mengetahui hubungan antara Sistem Informasi Manajemen dengan Efektivitas Kerja Pegawai Negeri Sipil pada Bagian Pengolahan Data Elektronik Provinsi Sulawesi Tenggara.

Populasi dalam penelitian ini adalah seluruh pegawai yang berstatus Pegawai Negeri Sipil yang bekerja pada Bagian Pengolahan Data Elektronik Provinsi Sulawesi Tenggara yang berjumlah 32 orang. Pengambilan sampel dilakukan dengan menggunakan metode sampel jenuh (sensus), yakni menggunakan seluruh populasi sebagai sampel (responden) disamping itu digunakan 2 orang informan yakni Kepala Bagian dan Kepala Sub Bagian Pengolahan Data Elektronik. Dalam penelitian ini digunakan análisis korelasi product moment dan análisis kualitatif.

Hasil penelitian menunjukkan bahwa sistem informasi manajemen yang digunakan oleh Bagian Pengolahan Data Elektronik Provinsi Sulawesi Tenggara rata-rata sudah baik, dan efektivitas kerja pegawai negeri di Bagian Pengolahan Data Elektronik Provinsi Sulawesi Tenggara juga rata-rata baik.
\end{abstract}

Kata Kunci: Efektivitas Kerja; Pengolahan Data Elektronik; Sistem Informasi Manajemen 


\section{PENDAHULUAN}

Pemanfaatan sistem informasi manajemen dalam era globalisasi dirasakan sangat mendesak, sehingga mengharuskan suatu instansi dapat segera menggunakan sistem informasi dalam melaksanakan kegiatan administrasinya sehingga memudahkan, mempercepat, transparan, tertib, terpadu, produktif, akurat, aman, efektif dan efisien dalam melaksanakan tugastugasnya, khususnya bagi tugas-tugas di bidang pemerintahan. Hal ini sejalan dengan pergeseran paradigma dari regulasi menghambat (wall regulation) menuju regulasi mendorong (enabling regulation), (Pusat Data Informasi Komunikasi dan Telekomunikasi Departemen Dalam Negeri, 2004).

Sistem Informasi Manajemen adalah sebuah bentuk sistem informasi yang ditujukan untuk melayani para pimpinan. Sebenarnya sistem informasi manajemen tersebut terfokus pada alat bantu untuk mempercepat para pimpinan memperoleh informasi. Suatu sistem informasi manajemen tidak hanya merupakan serangkaian gagasan konsep.

Sistem Informasi Manajemen adalah suatu sistem berbasis komputer yang menyediakan informasi bagi beberapa pemakai dengan kebutuhan yang serupa baik itu membuat keputusan maupun untuk memecahkan masalah. Dalam hal ini, sistem informasi manajemen dalam suatu organisasi mempunyai komponen-komponen fisik yang terdiri atas : perangkat keras (hardware), perangkat lunak (software), database, prosedur (procedure), dan manusia (brainware) yang saling berinteraksi untuk menyediakan data dan informasi yang tepat pada waktunya kepada pihak-pihak di dalam maupun di luar organisasi yang berkompeten. (Raymond Mcleod, JR (1996).

Sistem informasi manajemen merupakan sistem operasional yang melaksanakan beraneka ragam fungsi untuk menghasilkan keluaran yang berguna bagi pelaksana operasi dan manajemen organisasi yang bersangkutan. Struktur sistem informasi manajemen didasarkan pada apa yang harus dikerjakan oleh suatu sistem. Namun demikian, desainnya ditentukan oleh kebutuhan yang tidak saja harus bisa dikerjakan, melainkan juga yang harus bernilai. Inti pengertian Sistem Informasi Manajemen tentu saja terkandung dalam pekerjaan-pekerjaan sistematis seperti pencatatan agenda, kearsipan, komunikasi, di antara pimpinan-pimpinan organisasi, penyajian informasi untuk pengambilan keputusan, dan lain sebagainya.

Dengan berkembang pesatnya teknologi alat pengolah data komputer dan teknologi peralatan komunikasi, maka pekerjaan manajemen dan pelayanan masyarakat yang memerlukan dukungan data dan informasi juga mengalami kemajuan pesat. Pekerjaan manajemen pun berkembang jauh menjadi sangat rumit seiring dengan kemajuan era globalisasi. Tanpa dukungan informasi, maka manajemen suatu organisasi tidak akan dapat mencapai suatu tujuan yang direncanakan, apalagi untuk mencapai sasaran secara efektif dan efisien.

Biro Humas dan Pengolahan Data Elektronik Provinsi Sulawesi tenggara merupakan salah unit yang bertugas menyediakan data untuk berbagai kepentingan. Biro ini terdiri dari tiga (3) bagian, salah satunya adalah Bagian Pengolahan Data Elektronik sebagai unit yang 
Vol 2 No 2, Mei - July 2019. pp.75 - 83. Journal PUBLICUHO Faculty of Social and Political Sciences Halu Oleo University, Kendari, Southeast Sulawesi, Indonesia. ISSN 2621-1351 (online), ISSN 2685-0729 (print) Open Access at: http://ojs.uho.ac.id/index.php/PUBLICUHO/index

melakukan perumusan kebijakan teknis di bidang data elektronik dan penyusunan rencana program pembangunan dan pengembangan sistem informasi dan telematika. Dengan demikian Bagian Pengolahan Data Elektronik memerlukan dukungan kemampuan tenaga teknis, prosedur atau tata cara kerja serta perangkat lunak dan perangkat keras yang memadai guna menunjang kelancaran pelaksanaan tugas-tugas pokok dan fungsinya.

Fokus kegiatan Bagian Pengolahan Data Elektronik Provinsi Sulawesi Tenggara adalah Mengoptimalkan tugas dan fungsi Bagian Pengolahan Data Elektronik berdasarkan dukungan dana dan dukungan sumber daya manusia. Dengan adanya sistem informasi manajemen yang didukung oleh sistem informasi yang berbasis pada komputer dapat membantu pegawai dalam melaksanakan pekerjaan, sehingga para pegawai tidak mengalami kesulitan dalam bekerja dan menyelesaikan tugas-tugasnya dengan baik yang pada akhirnya dapat meningkatkan efektivitas kerja dan mampu membawa instansinya ke arah yang lebih baik.

Pelaksanaan sistem informasi manajemen pada Bagian Pengolahan Data Elektronik Provinsi Sulawesi Tenggara belum diterapkan dengan baik. Hal ini dapat dilihat antara lain dari penempatan sumber daya manusia yang kurang tepat dan penggunaan peralatan yang kurang memadai, sehingga mempunyai dampak terhadap efektivitas kerja pegawai. Selain itu, data-data yang dikumpulkan dari dinas-dinas daerah provinsi sering mengalami keterlambatan sehingga untuk memperoleh data yang akurat dan relevan membutuhkan waktu yang cukup lama. Disamping itu kurangnya komunikasi antara pimpinan dengan para bawahan dapat menyulitkan para bawahan untuk menyampaikan masalah-masalah yang terjadi pada setiap kegiatan.

Berdasarkan latar belakang di atas, maka fokus permasalahan dalam penelitian ini adalah bagaimana mana pelaksanaan sistem informasi dan efektivitas kerja yang dicapai oleh Pegawai Negeri Sipil pada Bagian Pengolahan Data Elektronik, dan apakah terdapat hubungan yang signifikan antara sistem informasi manajemen dengan efektivitas kerja Pegawai Negeri Sipil Pada Bagian Pengolahan Data Elektronik Provinsi Sulawesi Tenggara.

Tujuan penelitian ini adalah untuk mengungkapkan pelaksanaan sisten informasi manajemen dan efektivitas kerja Pegawai Negeri Sipil pada Bagian Pengolahan Data Elektronik Provinsi Sulawesi Tenggara, dan untuk mengetahui hubungan antara Sistem Informasi Manajemen dengan Efektivitas Kerja Pegawai Negeri Sipil pada Bagian Pengolahan Data Elektronik Provinsi Sulawesi Tenggara.

Hasil penelitian diharapkan dapat memberi kontribusi atau masukan bagi pimpinan organisasi terutama pada Bagian Pengolahan Data Elektronik Provinsi Sulawesi Tenggara dalam mengambil keputusan tentang penggunaan sistem informasi manajemen dalam usaha meningkatkan efektivitas kerja pegawainya. 


\section{METODE PENELITIAN}

Penelitian ini dilakukan pada Bagian Pengolahan Data Elektronik Provinsi Sulawesi Tenggara. Pemilihan lokasi didasarkan atas pertimbangan bahwa Bagian Pengolahan Data Elektronik Provinsi Sulawesi Tenggara sebagai unsur penunjang Pemerintah Daerah yang mempunyai tugas melakukan perumusan kebijakan teknis di bidang data elektronik dan penyusunan rencana program pembangunan dan pengembangan sistem informasi dan telematika, dimana dengan sendirinya memerlukan Sistem Informasi Manajemen yang memadai, guna menunjang kelancaran pelaksanaan tugas-tugas fungsi dan kewenangan.

Populasi dalam penelitian ini adalah seluruh pegawai yang berstatus Pegawai Negeri Sipil yang bekerja pada Bagian Pengolahan Data Elektronik Provinsi Sulawesi Tenggara yang berjumlah 32 orang. Mengingat jumlah populasi yang kecil, maka dalam penelitian ini menggunakan sampling jenuh (sensus) yaitu menggunakan seluruh populasi sebagai sampel (responden) dalam penelitian ini.

Pengumpulan data dalam penelitian ini, baik data primer maupun data sekunder dilakukan melalui: (1) penyebaran angket (Quesioner), (2) Wawancara (Interview), dan (3) Dokumentasi. Berdasarkan tujuan penelitian, maka data yang dikumpulkan akan diolah dan dianalisis dengan teknik : (1) distribusi frekuensi dan persentase, dan (2) teknik analisis korelasi product moment dimana mengkaji hubungan antara kedua variabel yaitu variabel Sistem Informasi Manajemen $(X)$, dan variabel Efektivitas Kerja $(Y)$. dengan menggunakan formulasi koefisien korelasi dari Sugiyono, (2003 : 214). Selanjutnya untuk menguji hubungan sistem informasi manajemen dengan efektivitas kerja pegawai digunakan uji t.

\section{HASIL DAN PEMBAHASAN}

\section{A. Deskripsi Variabel Penelitian}

Variabel dalam penelitian ini terdiri dari variabel Sistem Informasi Manajemen (X) dengan lima indikator yaitu perangkat keras (hardware), perangkat lunak (software), prosedur (procedure), manusia/personil dan Data base, dan variabel Efektivitas Kerja (Y) dengan tiga indikator yaitu : ketepatan waktu dan ketelitian, hasil kerja pegawai, melaksanakan tugas sesuai target dan aturan.

\section{Variabel Sistem Informasi Manajemen (X)}

Sistem Informasi Manajemen (SIM), dalam penelitian ini diukur dengan indikator-indikator : perangkat keras (Hardware), perangkat lunak (Software), database, prosedur (Procedure), manusia (Brainware).

Hasil penelitian dengan menggunakan tabel distribusi frekuensi menunjukkan bahwa variabel sistem informasi manajemen dengan sub variabel Perangkat keras (hardware) telah dianggap lengkap oleh responden (72\%), artinya ketersediaan perangkat keras (hardware) 
Vol 2 No 2, Mei - July 2019. pp.75 - 83. Journal PUBLICUHO Faculty of Social and Political Sciences Halu Oleo University, Kendari, Southeast Sulawesi, Indonesia. ISSN 2621-1351 (online), ISSN 2685-0729 (print) Open Access at: http://ojs.uho.ac.id/index.php/PUBLICUHO/index

pada Bagian Pengolahan Data Elektronik Provinsi Sulawesi Tenggara dalam mendukung segala aktivitas pekerjaan kantor khususnya dalam mengolah data sampai pada menyebarluaskan informasi sudah lengkap.

Untuk sub variabel perangkat lunak (software) menunjukkan bahwa $64 \%$ responden mengatakan ketersediaan program aplikasi telah sesuai dengan kebutuhan, dan $84 \%$ responden mengatakan bahwa penggunaan webside sudah sangat efektif. Hal ini menunjukkan bahwa ketersediaan program/aplikasi yang digunakan telah mendukung pelaksanaan pekerjaan. Hasil penelitian ini didukung pula dengan hasil wawancara Kepala Bagian Pengolahan Data Elektronik Provinsi Sulawesi Tenggara (Mei, 2009) yang mengatakan bahwa,

"ketersediaan program aplikasi yang digunakan dalam melaksanakan segala pekerjaan telah sesuai seperti program sistem administrasi aplikasi kepegawaian, dimana data-data yang berhubungan dengan kepegawaian Bagian Pengolahan Data Elektronik dibuat dalam bentuk aplikasi kepegawaian sehingga memudahkan dalam pencarian data-data pegawai".

Dari distribusi frekuensi variabel sistem informasi manajemen dengan sub variabel database menunjukkan bahwa $44 \%$ responden mengatakan bahwa data base belum tersedia dengan baik. Keadaan ini dibenarkan oleh Kepala Bagian Pengolahan Data Elektronik Provinsi Sulawesi Tenggara (Mei, 2009), yang mengatakan bahwa,

"database yang kita butuhkan kadang-kadang tidak dapat tersedia, hal ini disebabkan karena belum lengkapnya data-data yang dibutuhkan pada setiap kabupaten/kota, hanya sebagian kabupaten/kota saja yang mempunyai data-data yang lengkap seperti kota Kendari, kota Bau-bau, dan kabupaten Wakatobi, sedangkan kabupaten/kota lainnya masih belum lengkap"

Untuk sub variabel Prosedur (procedure), yang diukur dengan kendala yang terjadi dan informasi yang dihasilkan menunjukkan bahwa dalam pelaksanaan prosedur masih terdapat kendala-kendala dalam proses pengumpulan, pengolahan, dan penyalurannya, dimana sebahagian besar (72\%) responden mengatakan bahwa prosedur yang ada kadangkadang masih mengalami kendala karena kurangnya database dari instansi terkait disamping itu kurang akuratnya data, sehingga memperlambat proses penyebarluasan informasi.

Selanjutnya untuk sub variabel manusia (brainware) yang diukur dengan kemampuan menganalisis data, kemampuan mendesain program aplikasi, kemampuan mengoperasikan komputer, dan kemampuan memelihara peralatan perangkat keras (hardware), diperoleh hasil bahwa sebahagian besar (72\%) responden menunjukkan bahwa pegawai mempunyai kemampuan yang sangat baik. Untuk mengetahui lebih jelasnya mengenai kemampuan pegawai dalam menganalisis data maka dilakukan wawancara dengan Kepala Sub Bagian Pengolahan Data Elektronik Provinsi Sulawesi Tenggara (Juni, 2009), yang mengemukakan bahwa, 


\begin{abstract}
"rata-rata pegawai telah mampu dalam mengoperasikan peralatan komputer sedangkan untuk pemeliharaan peralatan perangkat keras (hardware) dipercayakan kepada operator komputer dengan cara melakukan perubahan dan perbaikan program-program yang ada serta melakukan pembersihan/scan terhadap virus-virus yang memungkinkan dapat merusak program-program aplikasi yang ada di dalam perangkat keras (hardware) tersebut. Dalam menganalisis data dan mendesain program aplikasi sudah ada yang mengerjakannya sesuai bidang masing-masing hanya saja sebagian pegawai membantu dalam mengolah data-data yang sudah ada sehingga terjadi hungan kerja sama yang baik antara unit kerja".
\end{abstract}

Dari keseluruhan jawaban responden terhadap keseluruhan pertanyaan yang mengangkut variabel sistem informasi manajemen kemudian dilakukan perhitungan dengan menggunakan skala likert maka secara kontinum hasil perhitungan perhitungan diperoleh nilai bobot sebesar 1143 yang berarti bahwa tanggapan responden terhadap pelaksanaan sistem informasi manajemen pada Bagian Pengolahan Data Elektronik Provinsi Sulawesi Tenggara adalah Baik.

\title{
2.Variabel Efektivitas Kerja (Y)
}

Efektivitas Kerja, adalah hasil kerja yang dicapai oleh pegawai dalam melaksanakan tugastugas yang dibebankan. Pada umumnya efektivitas kerja diukur melalui indikator-indikator sebagai berikut :

a) Ketepatan waktu dan ketelitian, indikator yang diteliti adalah ketelitian dalam bekerja serta bekerja dengan cepat dan tepat.

b) Hasil kerja pegawai, indikator yang diteliti adalah kualitas kerja, pekerjaan berjalan lancar, serta bermanfaat bagi organisasi.

c) Melaksanakan tugas sesuai target dan aturan, indikator yang diteliti adalah sesuai dengan target yang telah ditentukan, semua unit kerja bekerja sesuai dengan aturan/pedoman yang ada.

Hasil penelitian dengan menggunakan tabel-tabel distribusi frekuensi menunjukkan bahwa variabel Efektifitas Kerja yang diukur dengan ketepatan waktu dan ketelitian di atas menunjukkan bahwa 52\% pegawai telah bekerja dengan teliti. Disamping itu mereka juga telah bekerja dengan cepat dan tepat waktu (64\%). Hal ini menunjukkan bahwa kemampuan pegawai dalam menyelesaikan segala pekerjaan dan tugas-tugasnya adalah sudah cepat dan tepat.

Untuk mengetahui lebih jelasnya mengenai ketepatan waktu dan ketelitian pegawai dalam bekerja, maka dilakukan wawancara dengan Kepala Sub Bagian Pengolahan Data Elektronik Provinsi Sulawesi Tenggara (Juni, 2009), yang mengemukakan bahwa, "pegawai sudah teliti dalam melaksanakan tugas-tugasnya misalnya saja apabila ada kesalahan yang dilakukan dalam penulisan surat-surat maka mereka langsung memperbaikinya. Selain itu, beliau mengatakan juga bahwa, "pegawai pada Bagian Pengolahan Data Elektronik Provinsi Sulawesi Tenggara telah bekerja dengan cepat dan tepat waktu seperti pengerjaan laporan- 
Vol 2 No 2, Mei - July 2019. pp.75 - 83. Journal PUBLICUHO Faculty of Social and Political Sciences Halu Oleo University, Kendari, Southeast Sulawesi, Indonesia. ISSN 2621-1351 (online), ISSN 2685-0729 (print) Open Access at: http://ojs.uho.ac.id/index.php/PUBLICUHO/index

laporan yang akan diajukan kepada pimpinan sehingga pada saat di butuhkan laporan tersebut siap dilaporkan serta dalam pembuatan kenaikan gaji berkala (KGB) dimana apabila mereka tidak cepat dan tepat waktu dalam mengerjakannya maka akan merugikan pegawai yang lainnya dimana akan mengalami keterlambatan kenaikan gaji, sehingga mereka tidak akan menerima kenaikan gaji tersebut karena keterlambatan tadi, olehnya itu mereka senantiasa bekerja dengan cepat dan tepat waktu".

Selanjutnya mengenai sub variable hasil kerja pegawai, dan melaksanakan tugas sesuai target dan aturan, diperoleh hasil bahwa rata-rata $84 \%$ telah melakukan pekerjaan dengan baik, dimana telah menunjukkan kualitas yang baik, dapat dikerjakan dengan lancar dan dapat bermanfaat bagi organisasi, dan dilaksanakan sesuai target dan aturan yang berlaku.

Untuk mengetahui lebih jelas mengenai hasil kerja pegawai, maka dilakukan wawancara dengan Kepala Bagian Pengolahan Data Elektronik Provinsi Sulawesi Tenggara (Juni, 2009), yang mengemukakan bahwa,

"kualitas kerja pegawai dalam melaksanakan segala tugas-tugas yang diberikan dari pimpinan sudah baik, misalnya pada bagian tatausaha tugastugas yang diberikan seperti membantu pimpinan dalam mengatur surat-surat yang masuk/keluar dimana surat-surat tersebut ada yang harus di balas secepatnya namun dengan kualitas kerja pegawai yang baik maka surat-surat yang ada hampir tidak pernah mengalami keterlambatan dan kesalahankesalahan"

Dari keseluruhan jawaban responden terhadap keseluruhan pertanyaan yang mengangkut variabel Efektivitas Kerja kemudian dilakukan perhitungan dengan menggunakan skala likert maka secara kontinum hasil perhitungan menunjukkan bahwa nilai bobot sebesar 706 yang berarti bahwa tanggapan responden terhadap efektivitas kerja Pegawai Negeri Sipil pada Bagian Pengolahan Data Elektronik Provinsi Sulawesi Tenggara adalah Efektif.

\section{Hubungan Sistem Informasi Manajemen dengan Efektivitas Kerja Pegawai Negeri Sipil (PNS) Pada Bagian Pengolahan Data Elektronik Provinsi Sulawesi Tenggara.}

Untuk melihat hubungan variabel sistem informasi manajemen dengan efektivitas kerja PNS digunakan analisis korelasi product moment. Berdasarkan hasil analisis korelasi product moment diperoleh hasil perhitungan koefisien korelasi $(r)$ sebesar 0,624 yang berarti bahwa hubungan sistem informasi manajemen dan efektivitas kerja Pegawai Negeri Sipil berada pada kategori kuat, sedangkan koefisien determinasi sebesar 0,389 menunjukkan bahwa 39\% pencapaian efektivitas kerja Pegawai Negeri Sipil pada Bagian Pengolahan Data Elektronik Provinsi Sulawesi Tenggara ditentukan oleh penggunaan sistem informasi manajemen yang baik, sedangkan sisanya sebesar $61 \%$ ditentukan oleh faktor-faktor lain yang tidak diteliti dalam penelitian ini. Selanjutnya, dilakukan pengujian hipotesis dengan menggunakan uji- $t$ pada taraf/tingkat kepercayaan 95\% $(\alpha=0,05)$ Hasil pengujian menunjukkan sebagai berikut : 
Tabel 1. Uji signifikan koefisien korelasi ( $r$ )

\begin{tabular}{ccccc}
\hline Sampel $(n)$ & Koefisien korelasi & Koefisien determinan & thitung & $t_{\text {tabel }}(\alpha=0,05)$ \\
\hline 32 & 0,624 & 0,389 & $3,827^{*}$ & 1,714
\end{tabular}

Sumber: Hasil analisis, 2009

Dari hasil pengujian keberartian koefisien korelasi diperoleh nilai $t_{\text {hitung }}=3,827$, jika dibandingkan dengan tabel $(a=0,05)$ peroleh nilai tabel $=1,714$ dengan demikian, $t_{\text {hitung }}=$ $3,827>t_{\text {tabel }}=1,714$, yang berarti bahwa terdapat hubungan yang signifikan antara sistem informasi manajemen dengan efektivitas kerja pegawai negeri sipil (PNS) Pada Bagian Pengolahan Data Elektronik Provinsi Sulawesi Tenggara. Hal ini, berarti peningkatan efektivitas kerja pegawai negeri sipil (PNS) Pada Bagian Pengolahan Data Elektronik Provinsi Sulawesi Tenggara secara signifikan dipengaruhi oleh pelaksanaan sistem informasi manajemen.

Berdasarkan hasil analisis dan pembahasan di atas dapat diketahui bahwa terdapat hubungan yang signifikan antara sistem informasi manajemen dengan peningkatan efektivitas kerja pegawai pada Bagian Pengolahan Data Elektronik Provinsi Sulawesi Tenggara, hal ini tercipta karena adanya dukungan sarana dan prasarana sistem informasi manajemen yang cukup memadai serta didukung pula oleh pegawai yang berorientasi pada pekerjaannya serta mampu bekerja sesuai dengan bidangnya serta tugas pokok dan fungsinya masing-masing. Oleh karena itu, semakin baik sistem informasi manajemen yang terdapat pada Bagian Pengolahan Data Elektronik Provinsi Sulawesi Tengggara maka efektivitas kerja pegawai negeri sipil akan semakin meningkat pula.

\section{KESIMPULAN}

Berdasarkan analisis dan pembahasan, maka diperoleh kesimpulan bahwa Sistem informasi manajemen yang digunakan oleh Bagian Pengolahan Data Elektronik Provinsi Sulawesi Tenggara rata-rata sudah baik, dan Efektivitas kerja pegawai negeri sipil pada Bagian Pengolahan Data Elektronik Provinsi Sulawesi Tenggara juga rata-rata sudah baik.

Hubungan antara variabel Sistem informasi manajemen dan variabel Efektivitas kerja pegawai negeri sipil menunjukkan hubungan yang kuat dan positif, sehingga apabila penggunaan sitem informasi manajemen pada Bagian Pengolahan Data Elektronik Provinsi Sulawesi Tenggara semakin baik, maka Efektivitas kerja pegawai negeri sipil juga akan semakin baik.

\section{SARAN}

Pada Bagian Pengolahan Data Elektronik Provinsi Sulawesi Tenggara masil perlu ditingkatkan lagi dengan meningkatkan berbagai peralatan sistem informasi manajemen yang memadai serta didukung oleh pegawai-pegawai yang mempunyai keahlian di bidang masing-masing. 
Vol 2 No 2, Mei - July 2019. pp.75 - 83. Journal PUBLICUHO Faculty of Social and Political Sciences Halu Oleo University, Kendari, Southeast Sulawesi, Indonesia. ISSN 2621-1351 (online), ISSN 2685-0729 (print) Open Access at: http://ojs.uho.ac.id/index.php/PUBLICUHO/index

\section{DAFTAR PUSTAKA}

Amsyah, Zulkifli. 2005. Manajemen Sistem Informasi. Bandung : PT. Gramedia Pustaka Utama.

Davis, Gordon B. 1993. Kerangka Dasar Sistem Informasi Manajemen, Terjemahan Oleh Andreas, Adi Wardana, Jakarta : LPPM dan PT. Pustaka Binaman Pressindo.

2002. Management Information System Conceptual Condition. Alih Bahasa Andreass, Adi Wardana dan Bob Widya Hartono. Jakarta : LPPM dan PT. Pustaka Binaman Pressindo.

Dharma, Agus. 1991. Manajemen Prestasi Kerja, Pedoman Praktis Bagi Penyedia Untuk Meningkatkan Prestasi Kerja. Jakarta : Rajawali Press.

Fitriaty, Elly. 2005. Tinjauan Sistem Informasi Manajemen. Jakarta : Prehallindo.

Flippo, Edwin B. 1992. Manajemen Personalia Jilid I Edisi IV. Jakarta : Erlangga.

F.X. Soedjadi. 1997. Manajemen Sumber Daya Manusia. Jakarta : Toko Gunung Agung.

Hadari, Nawawi H. 1993. Manajemen Sumber Daya Manusia Untuk Bisnis Yang Kompetitif Cetakan I. Yogyakarta: UGM Press.

Kadir, Abdul. 2003. Pengenalan Sistem informasi. Yogyakarta : Andi

Mcleod, Raymond J.R. 1996. Sistem Informasi Manajemen Edisi Ke-8. Jakarta : PT. Indeks.

Murdick, Robert G. and Claggett, James R. 1993. Sistem Informasi Manajemen Modern. Ahli Bahasa: J. Jamil MBA, Jakarta.

Nuraida, Ida,. 2008. Manajemen Administrasi Perkantoran. Yogyakarta : Kanisius.

Scott, George, M. 2004. Prinsip-prinsip Sistem Informasi Manajemen. Penerjemah Achmad Nasir Budiman. Jakarta : Raja Grafindo Persada.

Silalahi, T.B. 1993. Sistem Pembinaan Pegawai Negeri Sipil dalam Kaitannya dengan Otonomi Daerah. Jakarta : Sekretariat Menpan.

Soesanto, Slamet. 2001. Administrasi Kantor Manajemen dan Aplikasi Sistem. Jakarta : Djambatan.

Sugiyono. 2003. Metode Penelitian Administrasi. Bandung : Alfabeta. 